\title{
Evolutionary Epidemiology of the COVID-19 Pandemic in Cameroon
}

Eba Obam Yannick ${ }^{1,4^{*}}$, Nnanga Nga ${ }^{1}$, Kagoue Simeni Luc Aime ${ }^{2}$, Yves Wasnyo ${ }^{1,3}$

\author{
${ }^{1}$ Faculty of Medicine and Biomedical Sciences, University of Yaounde 1 \\ ${ }^{2}$ Faculty of Health Sciences, University of Buea Cameroon \\ ${ }^{3}$ Yaounde Central Hospital Cameroon \\ ${ }^{4}$ Obili subdivisionnal Medical Center
}

DOI: $10.36347 /$ sjmcr.2020.v08i08.018

| Received: 16.08.2020 | Accepted: 24.08.2020 | Published: 30.08.2020

*Corresponding author: Eba Obam Yannick

Abstract

Original Research Article

Corona virus infection is an acute respiratory condition caused by a new human corona virus (SARS-CoV-2, the virus responsible for COVID-19. This virus belongs to group $2 b$ corona viruses. Transmission of this disease appears to occur through droplets, dispersed in the environment, coughing or sneezing. Human-to-human contamination occurs through manual contact or contact with secretions deposited on equipment and other objects of common use such as doorknobs of offices, transport cars. The virus spreads rapidly, leading to an escalation in the number of cases in the population. The application of barrier measures is a response to contain the emergence of new cases. This study presents a statistical analysis of the epidemiological profile of new cases, mortality and the number of patients cured in Cameroon. It emerges that the pandemic linked to the new corona virus is in a phase of exponential contamination in Cameroon. This situation calls on health sector actors and the government to adopt a rigorous policy to halt the evolution of the disease in the country.

Keywords: COVID-19, Coronavirus, Mortality, Pandemic, SARS-CoV-2.

Copyright @ 2020: This is an open-access article distributed under the terms of the Creative Commons Attribution license which permits unrestricted use, distribution, and reproduction in any medium for non-commercial use (NonCommercial, or CC-BY-NC) provided the original author and source are credited.

\section{INTRODUCTION}

COVID-19 is an acute respiratory disease caused by a new human corona virus (SARS-CoV-2, the virus responsible for COVID-19), which results in higher mortality in people 60 years of age or older and in people with underlying medical conditions such as cardiovascular disease, chronic respiratory disease, diabetes or cancer [1]. Since the outbreak of the corona virus (COVID-19) epidemic in Wuhan, China, in December 2019 [2, 3], the disease has continued to spread across major cities, countries and continents. As of 30 January 2020, WHO declared COVID-19 a global pandemic and a public health emergency of international concern [4]. After China, Italy, France, Spain, the United States of America and many other countries [3], the disease spread to Africa where the first case was detected in Egypt. It took 16 days from the first confirmed case to reach 100 cases and 10 days later the first 1,000 cases were reached. 3 days after the 3,000 case mark was passed [5]. Cameroon recorded its first positive COVID-19 case on March 6, 2020 [6]. The disease spread exponentially day by day to reach 658 cases by April 6, 2020 [7]. On 21 May Cameroon reported 528 cases in 24 hours [7] figures that are of concern not only to the government but also to many health professionals. This increase in positive cases is said to be due to the easing of barriers related to the deconfinement introduced by the authorities. Although the chronology of infection is under control to date, a more stringent response is needed to halt the progression of the pandemic.

\section{Methodology}

This study was conducted from 06 March to 06 June 2020 by collecting official data communicated by the Ministry of Public Health of Cameroon. The data were obtained by consulting the site of the said Ministry: www.minsante.cm then distributed and analyzed. 


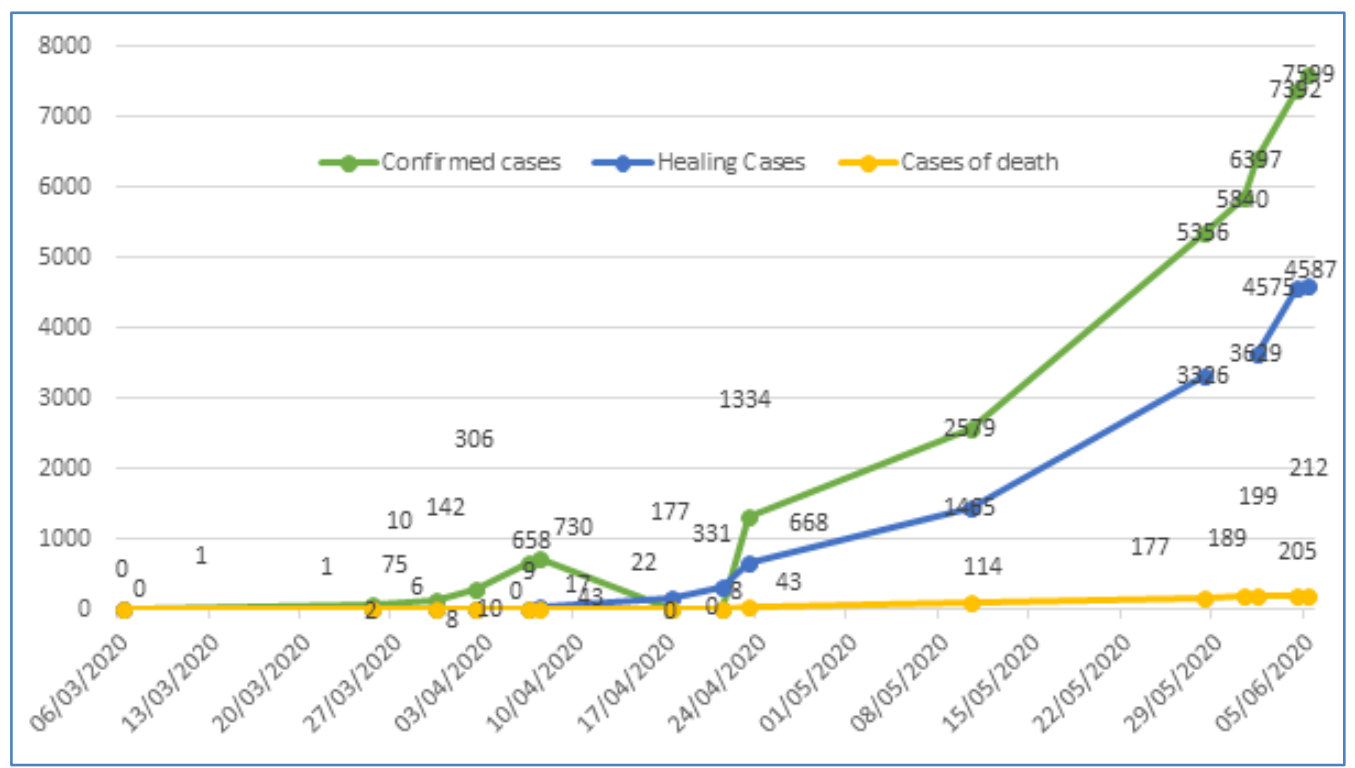

Fig-1: Evolutionary epidemiological profile of COVID-19 in Cameroon

\section{DiscuSSION}

SARS-COV-2 is a highly contagious virus at the inter-human level. Since the declaration of the first case in Cameroon, the country has entered an exponential progression of new cases. Although the country currently has an Infection Fatality Ratio (IFR) of $2.8 \%$ and a cure rate above $60 \%$, the corona virus continues to register escalating numbers, as to other countries where the disease has appeared [8]. As of 21 May 2020, Cameroon has recorded its highest score of 528 cases in 24 hours until reaching 7599 confirmed cases and 212 deaths as of 05 May 2020 [9]. Although the health authorities reassure that the pandemic is under control, the country has entered a "complicated phase" characterized by an acceleration of cases in communities. Only strict compliance with barrier measures such as hand washing, wearing a mask, social distancing, disinfection of spaces etc... could reduce the spread of infection although the epidemiological peak has not yet been reached to predict a period of falling disease in the country. As in most of the countries the appearance of new cases remains the same, the number of cases of recovery and deaths follows an increasing progression during the first 2 phases of the pandemic until reaching the epidemiological peak.

\section{Conclusion}

The present study carried out shows that the corona virus disease is still in the propagation phase. The figures show a similarity in the course of the disease as in all other countries where it has risen. Cameroon has become the epicenter of COVID-19 and the most affected country in Central Africa and the second in all of sub-Saharan Africa [10] despite the measures taken by the government to isolate and detect cases. Contamination in the population has greatly increased since the relaxation of barrier measures. Current epidemiological data do not reveal the full picture of the disease [10]. Even as the authorities in charge reassure that the situation is under control, most of the population seems to have let down their guard before the country reaches the epidemiological peak or declares a normal resumption of activities. All of which is worrying about the escalation of cases in recent days. It would be advisable for the authorities to strengthen barrier measures, to close down entertainment areas and to restrict international travel, which has been the real gateway for the disease to the country.

\section{REFERENCES}

1. Orientations pour la lutte anti-infectieuse dans les établissements de soins de longue durée dans le contexte de la COVID-19. Orientations provisoires, 21 mars 2020.OMS

2. Huang C, Wang Y, Li X, Ren L, Zhao J, Hu Y, Zhang L, Fan G, Xu J, Gu X, Cheng Z. Clinical features of patients infected with 2019 novel coronavirus in Wuhan, China. The lancet. $2020 \mathrm{Feb}$ 15;395(10223):497-506.

3. Hussin A. Rothan and Siddappa N. Byrareddy, Journal of Autoimmunity,

4. https://doi.org/10.1016/j.jaut.2020.102433

5. Gallegos A. WHO declares public health emergency for novel coronavirus. Medscape Medical News. Available at https://www medscape.com/viewarticle/924596. January 30, 2020.

6. L'OMS s'inquiète de l'accélération des cas de COVID-19 en Afrique. /https : /www.who.int/fr/news. Consulté le 25052020 à $11 \mathrm{~h} 30$ 
7. Communiqué de presse du Ministère de la santé publique du 6 mars 2020.www.minsante.cm consulté le 20/05/2020 à 10h41

8. Déclaration minsante du 06 avril 2020.www.minsante.cm consulté le 20/05/2020 https://www.researchgate.net/project/Analysisand- forecast- of- COVID- 19- spreading- inChina- and- Europe. Consulté le 09/06/2020
9. Communiqué de presse du Ministère de la santé publique du 5 juin 2020.www.minsante.cm consulté le 18 juin 2020 à 14 h41

10. https://www.unaids.org/fr/resources/presscentre/fea turestories/2020/may/20200511_covid19-cameroun consulté le 21/06/2020 à 10h10. 